\title{
Escrever a história através da culpa: as beatas do Juazeiro nos Arquivos do Vaticano (1889-1894)
}

\author{
Write the history through guilt: the religious women of Juazeiro in the \\ Vatican Archives (1889-1894)
}

Edianne dos Santos Nobre*

\begin{abstract}
Resumo:
No final do século XIX, a Diocese do Ceará (Juazeiro, Brasil) iniciou um processo para investigar a transformação de uma Hóstia consagrada em carne e sangue na boca da beata Maria Magdalena do Espírito Santo de Araújo. O fenômeno ocorreu em março de 1889 e os inquéritos foram produzidos entre 1891 e 1892, tendo sido enviados para a Santa Sé em 1893. Em 1894, a Santa Sé exarou um decreto, no qual, condenava Maria de Araújo e outras oito mulheres como embusteiras. Neste artigo buscamos reconstruir o percurso espiritual de duas destas beatas, Jahel Cabral e Maria da Soledade, a partir da análise do processo eclesiástico existente no Arquivo da Congregação para a Doutrina da Fé no Vaticano. Aventamos a hipótese de que estas mulheres buscaram, através dos seus testemunhos, construir trajetórias espirituais únicas, sem uma intermediação clerical direta, e, por isso, foram combatidas e condenadas pela Igreja Oficial.
\end{abstract}

Palavras- chave: beatas; santidade feminina; século XIX; Igreja Católica.

\begin{abstract}
:
In the late nineteenth century the Diocese of Ceará (Juazeiro, Brazil) has started a trial to investigate about the transformation of the Holy Particle in flesh and blood in the mouth of devout Maria Magdalena do Espírito Santo de Araújo. The phenomena occurred in March 1889 and the inquiries were produced between 1891 and 1892 that were sent to the Holy See in 1893. In 1894, the Holy See ditacte a decree in which, it condemned Maria de Araújo and eight other women like liars. The objective of this work is to analyze the trajectory of two devout women, Jahel Cabral e Maria da Soledade, from the analysis of an ecclesiastical inquiry that exists in the Archive of the Congregation for the Doctrine of the Faith at the Vatican. We developed the hypothesis that these women have sought to build unique spiritual paths through their testimonies, without the clerical intermediation, and therefore they were fought and condemned by the official Church.
\end{abstract}

Keywords: religious women; feminine holiness; XIX century; Catholic Church.

Artigo recebido em: 03 de maio de 2015 e aprovado em 18 de setembro de 2015.

* Doutora em História Social (UFRJ). Professora adjunta do Departamento de História da Universidade do Pernambuco. País de origem: Brasil. E-mail: e.snobre@gmail.com

Horizonte, Belo Horizonte, v. 13, n. 39, p. 1450-1479, jul./set. 2015 - ISSN 2175-5841 


\section{Introdução}

Condenadas pela Santa Sé como embusteiras, culpadas por falarem de uma experiência que não dependia da Igreja, as mulheres apresentadas neste artigo deixaram sua marca na História através de uma trajetória de dolo. Conhecidas simplesmente como beatas, as mulheres religiosas tinham no Juazeiro do século XIX um papel importante na composição da sociedade ${ }^{1}$. Respeitadas como virtuosas, podiam transitar entre os espaços, público e privado, sem medo de serem mal interpretadas ou condenadas. O termo "beata" era, praticamente, incorporado aos nomes das mulheres, e indicava, naquele contexto, não só uma condição religiosa, mas também social e cultural que não era exclusiva daquelas personagens, mas revelava muito da tessitura daquela sociedade e do laicato nos novecentos.

Neste sentido, é importante lembrar que o século XIX foi marcado pela tentativa da Igreja de consolidar um modelo de catolicismo que ficou conhecido como romanizado ou ultramontano. Uma doutrina que confrontasse as principais ameaças representadas pelas teorias racionalistas que ganharam força com as revoluções liberais do século anterior.

Foi durante o Concílio Vaticano I (1869-1870), que a desigualdade entre leigos e clérigos foi institucionalizada, reafirmando o estatuto de subordinação dos primeiros: "ninguém pode ignorar que a Igreja é uma sociedade desigual na qual Deus destinou uns a comandar, outros a obedecer. Esses são os leigos; aqueles são os clérigos” 2 . O projeto de reforma da Igreja proposto no Concílio Vaticano I teve

\footnotetext{
${ }^{1}$ Situado no sul do Ceará na região conhecida como Cariri cearense, o povoado de Juazeiro foi elevado à categoria de cidade em 22 de junho de 1911, tendo seu nome alterado para Juazeiro do Norte em 14 de junho de 1946 para se distinguir da cidade de Juazeiro na Bahia que era mais antiga.

2 Tradução minha: "personne ne peut ignorer que l’Eglise est une société inégale dans laquelle Dieu a destiné les uns à comander, les autres à obeir. Ceux-ci sont les laïcs; ceux-là sont les clercs" (Supremi Pastoris, Vaticano I apud Vauchez, 2006: 56).
} 
como principal bandeira a luta contra a autonomia dos poderes civis, situação que se complicou devido aos constantes embates entre a Igreja e o Estado3.

Aqui lidamos com um paradoxo que não pode ser ignorado: se, naquele contexto, a Igreja tentava firmar uma separação entre clero e leigos, por outro lado, foi também no final do século XIX que a atuação do público feminino ganhou importância, com o estímulo à fundação de congregações e confrarias femininas.

Temos aqui vários elementos que confluem em um mesmo contexto histórico: a institucionalização (e limitação) da atuação dos leigos na Igreja; a agregação e demarcação dos papéis concernentes ao público feminino; o combate ao catolicismo devocional e penitencial e consequente reforço de uma prática à romana. Ora, no Brasil todos esses elementos conviviam com uma prática católica, de herança colonial, que enfatizava os aspectos penitenciais ligados à mística dos séculos XVII e XVIII, o culto ao Jesus crucificado e práticas de mortificação.

É nesse contexto que encontramos essas mulheres. Ao me debruçar sobre a vida de uma beata em particular, encontrei a história de outras religiosas que diziam manifestar alguns fenômenos extraordinários4. A lista é grande: viagens ao Purgatório, Céu e Inferno, aparecimento de hóstias ensanguentadas, estigmas de crucificação, sangramento de crucifixos de metal maciço, relatos de visões, profecias, êxtases e comunhões espirituais. No entanto, o principal fenômeno narrado nos documentos, diz respeito ao sangramento da hóstia na boca da beata Maria de Araújo, em março de 1889, quando esta recebeu a hóstia das mãos do padre Cícero Romão Batista5.

\footnotetext{
${ }^{3}$ Segundo Hoornaert, a romanização significaria ainda uma europeização do catolicismo praticado no Brasil: "Penetram nada menos que 39 congregações masculinas de origem européia, assim como 109 femininas. Liquidam-se as irmandades leigas em benefício de associações religiosas controladas pelo clero" (1998: 40).

${ }^{4}$ No doutorado, analisei o percurso místico da beata Maria de Araújo no final do século XIX. A esta beata foi atribuído um suposto milagre, o sangramento miraculoso da hóstia, no momento da sua comunhão em seis de março de 1889. Maria de Araújo foi condenada pela Santa Sé em 1894, como embusteira e faleceu em 1914.

${ }^{5}$ Cícero Romão Batista nasceu em 24 de março de 1844 na cidade do Crato, filho de Joaquina Vicência Romana e Joaquim Romão Batista. Ordenou-se em 1871, passando a residir na cidade do Crato, de onde se originou o povoado de Juazeiro.
} 
Este acontecimento foi subitamente considerado como um "milagre" pelos sacerdotes e habitantes do povoado. Toda a notoriedade que o culto ao Sangue Precioso (como era chamado o sangue que vertia das hóstias de Maria de Araújo) ganhou, considerando-se principalmente que estava sendo corroborado pelos padres da região, chamou a atenção do bispo cearense na época, Dom Joaquim José Vieira 6 .

Para o bispo, o culto não poderia ser estimulado sem que houvesse antes uma investigação apropriada que confirmasse, segundo a doutrina da Igreja se os "fatos extraordinários" eram mesmo divinos e passíveis de culto. Outra queixa do bispo, dizia respeito ao fato de não ter sido comunicado imediatamente sobre a nova ocorrência de fenômenos e, principalmente, por haver sabido deles através dos jornais7.

Além do mal-estar criado pela falta de comunicação entre os padres e a Diocese, devemos considerar ainda o próprio contexto social e religioso daquele final de século no Brasil. Para o bispo, o culto não poderia ser estimulado sem que houvesse antes uma investigação apropriada que confirmasse, segundo a doutrina da Igreja, se os "fatos extraordinários” eram mesmo divinos e passíveis de culto. Dom Joaquim parecia ter a dimensão das consequências que um evento como esse podia acarretar, ao contrário do padre Cícero, seduzido pela ideia do milagre.

Dom Joaquim queria deixar claro que se um fato ocorria fora das vistas do diocesano, não poderia ser qualificado de milagre sem passar por uma investigação mais apurada. Diante disso, em 1891, o bispo instaurou um inquérito com o intuito de investigar o que acontecia no Juazeiro ${ }^{8}$. Para essa missão, Dom Joaquim escolheu dois padres muito conceituados da Igreja: o padre Clicério da Costa Lobo

\footnotetext{
${ }^{6}$ Sucedendo o bispo D. Luís Antônio, o bispo D. Joaquim José Vieira, assumiu o Bispado do Ceará em 24.02.1884 e em 14.03.1912 apresentou pedido de renúncia.

${ }^{7}$ Carta de D. Joaquim ao Pe. Cícero em 04.11.1889 in "Documentário", p. 28.

8 Dividido em dois inquéritos, executados entre 1891 e 1892, o Processo foi enviado para a Santa Sé em 1893 e terminou com a condenação de Maria de Araújo e das demais mulheres como embusteiras e com a suspensão a divinis do padre Cícero em 1894.
} 
(1839-1916), assumiu a função de Delegado da Comissão e o padre Francisco Ferreira Antero (1855-1929), a função de Secretário/Escrivão.

O primeiro era Doutor em Teologia, e morava no Rio de Janeiro quando foi convidado a assumir o cargo de secretário particular do bispo D. Luís Antônio dos Santos no Ceará em 1880. Assumiu também ali uma cátedra no Seminário Maior da Diocese e foi secretário do Sínodo Diocesano realizado em 1888. O padre Francisco Ferreira Antero, mais jovem, com 36 anos, era natural da cidade de Icó (sertão central do Ceará), ordenou-se em 1878 no Colégio Pio-Americano de Roma e dada a sua grande erudição, também havia sido cotado para uma vaga de Bispo Coadjutor no Ceará. Ele assumiu o papel de Secretário da Comissão Episcopal. Como podemos ver ambos os sacerdotes eram bem conceituados e considerados aptos para desenvolver tão relevante missão. A Comissão chegou a Juazeiro em 8 de setembro de 1891.

O primeiro inquérito instruído sobre os fatos do Juazeiro é uma peça documental completa, no sentido de que possui uma linha narrativa muito clara do começo ao fim. Grande parte do tempo da primeira Comissão foi dedicada às observações da transformação da hóstia e de outros fenômenos que ocorriam com as outras beatas, sobre os quais a Comissão nada sabia até chegar ao Juazeiro.

No corpo documental deste inquérito encontramos os depoimentos de oito beatas, ligadas ao padre Cícero e ao Apostolado da Oração, que provavelmente estavam na Capela de Nossa Senhora das Dores no dia do primeiro sangramento, embora não tenhamos certeza sobre isso. Neste artigo analisaremos o percurso de duas beatas: Jahel Cabral e Maria da Soledade. Mais do que meras informantes, elas reivindicaram uma participação mais ativa nos acontecimentos de 1889, como analisaremos a seguir. 


\section{As escolhidas para a Ceia do Senhor}

[...] aquelas que na busca incessante pela perfeição cristã, enveredavam pelo misticismo, despertando a devoção de outras mulheres. Eram as místicas e visionárias que em suas visões de Cristo e diálogos com os santos confirmavam os dogmas e os ensinamentos da Igreja (ALGRANTI, 1993, p. 307).

Se Maria de Araújo era vista como a esposa consagrada de Cristo por manifestar o sangramento da hóstia, as outras mulheres que depuseram no primeiro inquérito podiam ser consideradas as damas de honra daquela união, as convidadas para a ceia do Senhor. Quase desconhecidas da historiografia dedicada ao padre Cícero e ao Juazeiro, e raramente nomeadas, essas mulheres só deixaram sua marca na História devido aos depoimentos que prestaram no Processo Eclesiástico iniciado em 1891.

Citadas, vez ou outra, na correspondência trocada entre o bispo Dom Joaquim e o padre Antônio Alexandrino de Alencar'9, chega um momento, precisamente após suas retratações, que elas somem sem deixar rastros. A rigor, os relatos dessas mulheres seguem o mesmo padrão e as visões e revelações narradas em seus depoimentos, reforçam a necessidade de levar o processo diretamente ao Papa. Todas elas justificaram a ocorrência dos fenômenos pela tópica da Segunda Vinda de Cristo e da crise na Igreja Católica, aludindo à Paixão de Cristo como motivadora das visões e revelações:

Eu muitas vezes, vi distintamente Nosso Senhor a derramar sangue de seu coração e de suas mãos, dizendo, hei de derramar muitas vezes sangue, para chamar assim o povo a mim, como muitas vezes vi Nosso Senhor no Purgatório a derramar ali sangue de seu coração e de suas mãos, dizendo então que tantas outras vezes havia de derramar aqui no Juazeiro o seu mesmo sangue, para o fim de confirmar o povo na fé dos mistérios do amor de seu coração (CABRAL, 1891)10.

\footnotetext{
${ }^{9}$ Natural de Assaré, pequena cidade próxima ao Crato, o padre Alexandrino se formou sacerdote em 1874 e trabalhou nas cidades de Araripe, Quixadá e Crato.

${ }^{10}$ Aditamento de Jahel Wanderley Cabral de 05.10.1891 in "Cópia autêntica", p. 51.
} 
A primeira beata a depor no primeiro inquérito, após Maria de Araújo, foi Jahel Wanderlei Cabral, em 15 de setembro de 1891. Natural de Juazeiro, era solteira e tinha 31 anos em 1891, sabia ler e escrever, ao contrário da maioria analfabeta ou que só assinava o nome, e sua família era uma das mais importantes da região. Infelizmente, a exemplo das outras beatas, pouco sabemos sobre sua trajetória ou como chegou ao Apostolado da Oração.

Quando perguntada se sabia ou tinha ouvido falar sobre as visões de Maria de Araújo, Jahel surpreendentemente respondeu que não só sabia sobre essas visões, como "ela própria viu muitas vezes Nosso Senhor a derramar sangue, o que se deu cerca de dois anos antes das atuais manifestações” (CABRAL, 1981)11. É provável que essa afirmação tenha causado estranheza na Comissão, uma vez que pelo menos na documentação anterior ao Processo (basicamente as cartas trocadas entre o bispo e os padres do Cariri) ainda não se tinha ouvido falar de fenômenos manifestados por outras mulheres.

Ela disse ainda, ter testemunhado várias vezes, a transformação das hóstias em sangue, carne e coração humano, mas que isto já lhe tinha sido revelado antecipadamente em espírito. Da primeira vez, Deus lhe ordenou que fosse "em espírito” fazer uma comunhão em Roma, "para o fim de fazer confirmar com sua autoridade [do Papa] os milagres de Juazeiro". Em Roma, o Santo Padre (na época Leão XIII) lhe teria perguntado de onde era, qual seu nome e o objetivo de sua visita, ao que ela respondeu que "vinha da parte de Deus, anunciar-lhe que Deus mesmo queria, que, por sua autoridade, confirmasse os milagres operados no Juazeiro" (CABRAL, 1891) ${ }^{12}$.

Veremos que a narrativa de Jahel se diferenciou em alguns pontos em relação à das outras beatas. Primeiro, pelo detalhamento das viagens espirituais a Roma, o que é relevante, dado que ela era, possivelmente, a mais culta do grupo e, provavelmente, lera algo sobre a capital italiana (nesse momento muitos jornais já

${ }^{11}$ Depoimento de Jahel Wanderlei Cabral de 15.09.1891 in "Cópia autêntica", p. 22.
12 Depoimento de Jahel Wanderlei Cabral de 15.09.1891 in "Cópia autêntica", p. 22. 
circulavam na região). Segundo, por sua "intimidade" com Deus (ela raramente cita Jesus Cristo), ela diz, por exemplo, que quando foi chamada a comparecer diante da Comissão, sentiu-se aflita e ansiosa por não se julgar preparada e:

[...] viu o Padre Eterno [Deus Pai] que pondo-lhe [sic] a mão direita sobre o ombro esquerdo dela lhe ordenou que fosse perante o Padre confessor, para receber a benção e em seguida recebesse, digo, obedecesse à citação para maior honra e glória dele, pois para isso se achava encarregada da parte dele ( CABRAL, 1891) ${ }^{13}$.

Ela dá a entender que justamente por isso era a única autorizada a "registrar em livro essas revelações”, o que não sabemos se chegou a fazer. No entanto, ressaltou em seu depoimento que era "por Ele obrigada debaixo de juramento não somente a escrevê-las, senão ainda comunicá-las ao confessor”. Prometendo fazer um memorial de suas experiências, em 5 de outubro, menos de um mês depois, Jahel procurou a Comissão a fim de fazer um aditamento ao seu primeiro depoimento "equivalentemente ao memorial que se obrigara a dar, relativamente a algumas revelações que há tido acerca dos fatos dados, e por se dar nesta povoação"(CABRAL, 1891) ${ }^{14}$.

Veremos que a experiência de Jahel também é distinta das outras mulheres, porque ela foi uma das poucas na qual o sangue aparece somente nas visões, não tendo ela mesma, nenhum tipo de sangramento corporal. É importante destacar aqui o uso das expressões: "Vi distintamente", "Eis que vi", "Eu vi”, presentes no relato de Jahel e no relato das beatas que a seguiram, as quais funcionavam de modo a ressaltar sua autoridade, pois as expressões sugerem que elas não estavam sonhando nem em estado de vigília (sono leve), mas orando, meditando ou em êxtases e viram, deste modo, ninguém teria autoridade para contradizê-las.

As visões são as percepções sobrenaturais de pessoas ou objetos, invisíveis aos olhos (BORRIELO, 2003). Segundo Leila Algranti, as visões místicas são, nesse

\footnotetext{
${ }^{13}$ Depoimento de Jahel Wanderlei Cabral de 15.09.1891 in "Cópia autêntica", p. 22.

${ }^{14}$ Aditamento de Jahel Wanderley Cabral de 05.10.1891 in "Cópia autêntica", p. 51.
} 
caso, o principal canal de comunicação da beata com a divindade e esse tipo de prática "parece estar atrelada à condição de beata ou beato” (ALGRANTI, 1993, p. 91). Assim, como lembra Jean Franco: "Ese acceso directo a lo sobrenatural concedía a la monja mística la misma autoridad irrefutable de que goza el periodista que investiga y siempre puede decir: 'yo lo presencié”" (FRANCO, 1993, p. 36). Jean-Claude Schmitt também alerta que não podemos julgar a "veracidade" da visão ou do sonho, pois apesar de não sabemos como "realmente" a experiência se deu, também está em jogo a narrativa e os recursos linguísticos e semânticos utilizados pelos narradores (SCHMITT, 2007, p. 335).

A definição mais comum é aquela dada por Santo Agostinho, com destaque para os três gêneros de visões: as visões "corporais" que dependem dos sentidos do corpo, as visões "espirituais" que advém da imaginação e as visões "intelectuais" que surgem do raciocínio, da razão pura (SCHMITT, 1999, p.38). A visão corporal (Visio corporalis) é o próprio sentido da visão e a visão intelectual (Visio intelectualis) é a mais alta na hierarquia porque "provém da razão do homem (mens, ratio) e visa a contemplação direta de Deus" (SCHMITT, 1999, p. 39). Entre essas duas, a visão espiritual (Visio spiritualis) se sobressai porque é através dela que:

[...] o 'espírito' do homem (não os sentidos de seu corpo e tampouco a mens, a parte superior da alma) percebe 'imagens' ou 'semelhanças' de corpos (e não os próprios corpos). A função da alma que entra em jogo aqui é a imaginatio, poder intermediário e mediador entre sensus e mens, que recebe e elabora as imagens [...] (SCHMITT, 1999, p. 39).

Ainda a partir de Santo Agostinho, quanto mais clara a visão, mais verdadeira seria a revelação, isto é, "quanto menos enigmática, mais certa era a origem divina” (LIMA, 2005, p. 76). No caso das beatas, elas veem, durante a oração ou a meditação. Entram em êxtases e podem ver Jesus, Maria, anjos e santos, além disso, podem ter revelações que se assemelham ou são uma espécie de dom da profecia. 
Segundo Algranti, mulheres que levavam uma vida devotada à Igreja e ainda apresentavam históricos de reprodução de fenômenos sobrenaturais, se identificavam de imediato com a vocação piedosa e, ao mesmo tempo, com suas visões e êxtases quase sempre acompanhados de dores intensas tendiam a ratificar os dogmas da Igreja Católica.

Assim, seguindo o modelo arquetípico de visionária apresentado por Algranti, no qual, a visionária é "aquela que percebe, ou imagina perceber, por meio de comunicações sobrenaturais, coisas ocultas aos homens [...]” (ALGRANTI, 1999, p. 309), inferimos que nada impedia essas mulheres de manifestar fenômenos extraordinários ou de se comunicar com Jesus Cristo, Maria e outros santos, porque a vida destes era também tomada como exemplo a ser seguido:

\begin{abstract}
Por meio de visões oníricas ou imaginárias, as mulheres não só transmitiam os ensinamentos da Igreja, como serviam muitas vezes como porta-vozes da vontade divina. Em suas visões entravam numa comunhão com Deus [...] a mística visitava os céus, o inferno e o paraíso. Avistava-se com as almas no purgatório e ajudava-as através de suas próprias penitencias a atingirem a salvação (ALGRANTI, 1993, p. 307).
\end{abstract}

Tomando as devidas proporções que separam essas mulheres das beatas e santas da Idade Média, podemos inferir que essas "visões" foram imagens criadas a partir de elaborações que envolvem o contexto religioso e social onde elas viviam, as instruções morais e religiosas que receberam e claro, sua necessidade de imitar os santos.

Em seu aditamento, Jahel narrou duas magníficas visões que remetem a um dos arquétipos mais conhecidos das visões relacionadas à Paixão de Cristo: o lagar místico. Sendo uma das imagens perpetuadas tanto na literatura cristã como na arte religiosa desde o século XIII, a imagem desse tanque que abrigava o sangue que escorria das chagas de Jesus tinha como objetivo atrair a atenção dos fieis para os sofrimentos de Cristo: 
Assim como o cacho de uvas era esmagado no lagar, Cristo estava sujeito às opressões da cruz e aos sofrimentos da paixão. Chegou-se até mesmo a representar a imagem surpreendente do Pai ativando ele mesmo a prensa do lagar que fazia jorrar o sangue do corpo de Cristo (GÉLIS in CORBIN, 2008, p. 40).

A primeira visão narrada por Jahel Cabral datava de meados do mês de julho de 1890 quando orava na Capela de Juazeiro às oito horas da manhã:

[...] eis que vi o mundo a sofrer uma grande tempestade, depois da qual tive de ver pássaros de todas as qualidades e de todas as cores, bebendo sangue contido em uma grande caixa; então um deles olhou para mim, e com o bico tinto de sangue me disse: estes pássaros são almas de toda qualidade, as quais virão de todas as partes e lugares a beber sua salvação no sangue de Nosso Senhor derramado aqui neste lugar. Esta visão foi seguida de outras (CABRAL, 1891)15.

É provável que essa seja uma alusão direta ao Juazeiro como a "grande caixa" na qual as pessoas iam buscar a salvação. A metáfora também pode ser uma referência à caixa de vidro que guardava os panos manchados com o sangue que brotava das hóstias sanguinolentas de Maria de Araújo. A imagem dos pássaros, possivelmente, alude aos peregrinos que chegavam todos os dias ao Juazeiro, vindos de "todas as partes e lugares" em busca da remissão dos pecados, de graças ou da salvação (CAMPOS, 2004) ${ }^{16}$. Mais adiante, no mesmo aditamento ela diz: "Desde a vez primeira que apareceu aqui sangue nas hóstias consagradas me foi revelado divinamente que aqui (na Capela do Santíssimo) seria como outra piscina, onde muitos se lavariam assim na alma, como no corpo" (CABRAL, 1891) ${ }^{17}$.

Em outro momento, o coração de Jesus Cristo é representado como um "rio que regava toda a terra”, um rio que, segundo Jahel, a Diocese cearense queria secar com a luta para destruir o culto ao Sangue Precioso e as peregrinações. Por exemplo, ela narra que no dia 29 de julho de 1891, ouvindo do padre Cícero que o

\footnotetext{
${ }^{15}$ Aditamento de Jahel Wanderley Cabral de 05.10.1891 in "Cópia autêntica", p. 51.

${ }^{16}$ Arquetipicamente, os pássaros fazem referência ao trânsito entre o céu e a terra, seriam mensageiros divinos e representariam os anjos, seres que "brilham como o Sol, têm o nome de Deus inscrito no peito e trazem a palma, símbolo da vitória contra o mal, e a cruz, símbolo maior para o cristão" (CAMPOS, 2004, p. 107).

17 Os depoimentos subsequentes da beata Jahel, salvo quando referenciados, foram retirados do: Aditamento de Jahel Wanderley Cabral de 05.10.1891 in "Cópia autêntica", p. 53-55.
} 
bispo não acreditava que o sangue derramado ali era de Jesus Cristo, mas que seria um sangue "trazido pelos anjos" teve uma visão na qual o próprio Deus conversava com o padre Cícero:

[...] olha para mim homem, e reanima tua fé, lembra-te do que tantas vezes te hei dito [sic] que este sangue é o sangue do coração de Jesus; então eu disse, mas o Bispo quer que ele diga que não é o sangue de Jesus Cristo, mas um sangue trazido pelos anjos. Ele disse então, quem é maior eu ou o mundo todo? E nesta ocasião eu havia, digo, eu via que ele fechava tudo em sua mão, até mesmo o Papa era ele quem governava. (CABRAL, 1891)

Em seguida, vemos surgir em seu relato um Deus indignado, alertando que se o derramamento do seu sangue serve para salvação, também serviria para punição: "o sangue que derramei e [que] hei de derramar servirá de castigo para os que não acreditarem na minha onipotência”. Nos relatos de Jahel temos um Deus enfurecido, que critica e contra-argumenta as declarações do bispo:

Santo Thomaz não disse que aquele sangue derramado das hóstias, era sangue trazido pelos anjos, se assim fosse, como teria ele feito, em tantos livros, tantos atos de desagravo ao Coração de Jesus no S. S. Sacramento? Se é assim - um sangue trazido pelos anjos - então que se acabe com todas as obras de Santo Thomaz. Pergunte ao Bispo se quando eu instituí o S. S. Sacramento, não era Homem-Deus? Maior humilhação foi a que eu me sujeitei, instituindo o S. S. Sacramento, do que a de encarnar eu no ventre de uma Virgem, fazendo-me menino, e passando por todos os passos de minha vida humana até a morte de cruz. Semelhantemente maior é a humilhação de estar eu presente na eucaristia até a consumação dos tempos, do que a de derramar nela o meu sangue. (CABRAL, 1891).

Neste sentido, o aditamento feito por Jahel é muito mais rico que seu primeiro depoimento. Abundam os diálogos com o "Padre Eterno", este sempre argumentativo e reclamante do seu direito de voltar a terra e derramar seu sangue pela segunda vez, ressaltando que o principal motivo da descrença no milagre eucarístico seria a falta de fé dos seus próprios ministros: 
Não é de admirar que não entendam o mistério de derramar-se sangue das hóstias consagradas, sangue que é meu, porque a fé já está se acabando. Quando eu vim ao mundo não foram os Pontífices e Sacerdotes que deram a sentença de morte?! (CABRAL, 1891).

Aqui, a crítica era direcionada diretamente ao bispo Dom Joaquim que, como representante da Igreja, recusava-se a autorizar o culto e a enviar o processo para Roma. É difícil acreditar que esse texto foi tomado literalmente da fala de Jahel. Sabemos que ela podia ler e escrever, mas não sabemos a que tipo de literatura ela teve acesso, capaz de permitir a citação de São Tomás de Aquino e mesmo sobre qualquer questão doutrinal que envolvia a origem do sangue.

O aditamento de Jahel foi feito em 5 de outubro, como dissemos anteriormente. Considerando que os padres da Comissão estavam no povoado há menos de um mês, é possível questionar: Já estariam eles seduzidos pela crença no milagre a ponto de intervir ou influenciar no texto de Jahel? Uma vez que o relato dela indica conhecimento de questões doutrinais caras à Igreja, podemos questionar também: em que medida, há um "ajuste" da fala da beata de modo a tornar mais palpável sua relação direta com Deus e com a religião?

Jahel se manifestou sobre minúcias do caso, referindo-se sempre aos fenômenos como algo que ocorria independente da presença de Maria de Araújo, que, inclusive nem é citada no aditamento. Sobre a ordem dada pelo bispo, de destruir e queimar os panos manchados de sangue, Cristo lembra, em uma das visões de Jahel, que "[...] os Judeus queriam tirar-me daquela cidade alegando que não queriam outro rei, mas agora que estou no S. S. Sacramento, só para fazer o bem, tentam os homens para tirar-me do mundo até queimando-me".

Outro diferencial das visões de Jahel é a presença de personagens inéditos, como Verônica "com o pano de que se tinha servido para limpar o rosto de Nosso Senhor". Um dado curioso é que a história de Verônica (Bernike, em grego: "imagem verdadeira") vem da tradição oral, posteriormente incorporada ao livro 
apócrifo “Atos de Pilatos”. Parte da tradição afirma que Verônica era a mesma mulher que havia sido curada de um sangramento que durava doze anos (Bíblia de Jerusalém, Lc 8, 40-48). As visões com Maria também abundavam no relato da beata que, certa vez,

[...] vi Nossa Senhora toda vestida de verde dizendo então: remetam ao Papa o processo que se há de fazer, o que respondendo eu que só seria remetido ao Papa se o Bispo mandasse, como me disse o padre [Cícero], ela replicou: remetam para o Papa”. (CABRAL, 1891).

Essa visão possui elementos muito interessantes como a própria cor do vestido de Maria: o verde, que em algumas pinturas religiosas serve para indicar a esperança da salvação promovida pelo Messias (DELUMEAU, 2003, p. 158). Além disso, a aparição da Virgem nas profecias pedindo que fosse feita uma cópia do Processo para ser levado à Santa Sé garantindo a resolução dos problemas que houvessem, ratifica a atuação de Maria como intermediadora entre o fiel e Jesus/Deus.

Não por acaso, os oitocentos foi o grande século das aparições marianas (Salette, 1846; Lourdes, 1858; Pontmain, 1871, entre outras) e da consolidação da presença de Maria nas orações e nos lares católicos. Ainda sobre a citação acima, é notável que apareça pela primeira vez, um dado que se tornará recorrente: a ideia de que o Papa seria a favor dos milagres, pois ele mesmo não aprovara outros tantos?

As determinações exaradas na Decisão Interlocutória, de julho de 1891, também foram criticadas, ainda que de forma indireta, nos relatos de Jahel. Na visão, o próprio Deus (Eterno Padre) a tomou pelas mãos e a levou em espírito até a casa do Bispo em Fortaleza em setembro de 1891:

[...] quando ali chegamos, chamou ele pelo Bispo e ele [o bispo] não respondeu, o que se deu depois, digo, então eu indiquei que melhor seria subirmos, e o Eterno Padre disse em resposta: não, vamos ser os pequenos para depois sermos os grandes. Chamou pela segunda vez o Bispo, e vindo 
então algumas pessoas, da casa para saber do que queria, disse o Eterno Padre que queria falar com o Bispo mesmo, ao que ficando eles como que indiferentes, chamou terceira vez o Eterno Padre pelo Bispo, que não acudiu ao chamado, quando então disse o Eterno Padre - está vendo? Já é a terceira vez que o chamo, vamos embora, e nesse ínterim traçou uma cruz sobre a porta. (CABRAL, 1891).

O texto de Jahel critica o orgulho e a intolerância de D. Joaquim, que segundo ela, teria se recusado em atender à vontade de Deus, manifestada no próprio desejo do povo de Juazeiro de ter os fenômenos aprovados. Há ainda, a insinuação de que o bispo não estaria conectado espiritualmente com a divindade como elas estavam e os funcionários do bispo, da mesma forma não conseguem intuir que aquele que se apresenta à sua frente é o próprio Deus.

Para o bispo, seguramente um relato como esse, era uma afronta sem precedentes, pois ratificava a dispensa de uma intermediação entre elas e Deus. O relato denota ainda a livre confrontação ao bispo, por sua condição, autoridade máxima da Igreja na Província e que, portanto, deveria ser obedecido e não desrespeitado. Mas o que sentiram os padres da Comissão, tidos como "ilustrados" pela Diocese e que deveriam manter uma posição de desconfiança diante desse tipo de narrativa que confrontava a autoridade diocesana?

O único documento que nos chegou às mãos e dá uma ideia dos sentimentos da Comissão, especificamente, do Delegado desta, é uma carta enviada ao bispo em 13 de setembro de 1891, isto é, antes mesmo do aditamento de Jahel. Nesta carta, o padre Clicério Lobo fala que até então, testemunhara juntamente com "o Rdo. Secretário e mais pessoas fidedignas [os fatos] aqui dados, de um caráter de sobrenaturalidade divina [...] Há de certo muita coisa singularmente extraordinária"18. O Delegado não afirma acreditar piamente que as manifestações sejam mesmo divinas, mas não descarta a possibilidade, e é nesse espaço que a crença começa a se formar.

${ }^{18}$ DHDPG/CRB 04, 49: Carta do Pe. Clicério a D. Joaquim de 13.09.1891. 


\section{0 purgatório na terra}

Maria Leopoldina Ferreira da Soledade depôs em 17 de setembro de 1891, e, assim como Jahel, também teve visões importantes detalhadas com erudição e riqueza poética, incluindo citações em latim e conhecimento de dados relevantes sobre a Igreja de Roma. Ela tinha 29 anos, sabia ler e escrever e vinha de uma família de posses do Crato. $\mathrm{O}$ fato de haverem mulheres que pertenciam às esferas mais altas da sociedade caririense, denota um horizonte de possibilidades no qual a "experiência mística" atinge a todos ou onde todos se sentem partícipes desta, e, demonstra como esse "horizonte" era acionado por mulheres de diversas posições sociais: pobres e abastadas, analfabetas e alfabetizadas.

Os padres da Comissão seguiram o roteiro usual de perguntas, até que em dado momento, perguntam diretamente à testemunha se ela também tinha visões e revelações. Notamos que há uma mudança sutil por parte da própria Comissão que após o depoimento de Jahel, atenta para as experiências particulares de cada mulher e não somente às de Maria de Araújo.

Outro elemento diz respeito a uma espécie de "concorrência" que se instaura entre essas mulheres. Eram todas íntimas de Deus, todas eram instrumentos Dele! Já no depoimento de Jahel percebemos que ela não deseja falar sobre Maria de Araújo, mas sim da sua própria experiência e, aos poucos vai se constituindo esse grupo de mulheres que afirmavam terem sido escolhidas por Deus.

Perguntada sobre suas experiências, Maria Leopoldina respondeu que no ano anterior, em dezembro de 1890, quando fazia uma penitência em favor das almas do Purgatório, "lhe foi revelado achar-se ali o Corpo, o Sangue, a alma e a divindade de Nosso Senhor Jesus Cristo" que se oferecia "como vítima de expiação 
ao Eterno Padre pela salvação do mundo” e que não se tentasse compreender o que ali ocorria, pois era "um mistério de amor, além da razão humana”19.

Enquanto nas revelações de Jahel o mote principal era o da caixa cheia de sangue, nas de Maria da Soledade predominavam as representações angélicas e de almas do Purgatório. As representações sobre o sangue dão lugar às imagens de fogo e às citações em latim:

Eu sou Jesus, uma vítima pura, a santa vítima, uma vítima sem mancha: vivificada no coração e sangue dos pecadores. Veja, não faças isso... sou servo teu e de teus irmãos que guardas o testemunho de Jesus. O testemunho de sangue de Deus é o espírito de profecia. Eu sou a videira verdadeira, a vítima santa, vítima pura, vítima sem mancha. É santo e beato aquele que tomar parte na segunda redenção (SOLEDADE, 1891) ${ }^{20}$.

Esse trecho parece uma adaptação de Apocalipse 19,10: “Caí então a seus pés para adorá-lo, mas ele me disse: 'Não! Não o faças! Sou servo como tu e como teus irmãos que têm o testemunho de Jesus. É a Deus que deves adorar!'. Com efeito, o espírito da profecia é o testemunho de Jesus”.

Ressaltando a qualidade profética das revelações e visões, a citação em latim no depoimento de Maria da Soledade, vem dar força à narrativa. Além disso, outro recurso discursivo importante utilizado pela beata, encontrado também em outros depoimentos, é o de fazer Jesus Cristo falar em primeira pessoa. Quando a afirmação era muito forte ou questionava de algum modo a autoridade da Diocese, as mulheres colocavam Cristo como protagonista, recurso expressivo que, de certo modo, retirava delas a responsabilidade total sobre o que foi dito.

Neste sentido, é interessante notar que exatamente o mesmo texto já tinha aparecido no aditamento do padre Cícero em 14 de setembro, ou seja, um dia antes

\footnotetext{
${ }^{19}$ Os depoimentos subsequentes da beata Maria da Soledade, salvo quando referenciados, foram retirados do: Depoimento de Maria da Soledade em 15.09.1891 in "Cópia autêntica", p. 23-25.

20 Tradução nossa: "Ego sum Jesus, hostia pura, hostia sancta, hostia immaculata: vivificavi sanguinem cordis ad peccatores. Vide nefeceris... Conservus tuus sum et fratrum tuorum habentium testemonium Jesu. Deum ador [sic] testemonium sanguinis mei et espiritus prophetiae. Ego sum vitis vera, hóstia sancta, hostia pura, hóstia immaculata. Beatus et Sanctus quihabet partem in redemptione secunda".
} 
de Maria da Soledade comparecer diante da Comissão ${ }^{21}$. No seu relato, Cícero diz à Comissão que teve a revelação após a celebração de uma missa em honra ao Sagrado Coração de Jesus:

Consultando eu a Nosso Senhor diante de uma hóstia consagrada, sobre a espécie do sangue aparecido nas hóstias que se davam em comunhão a Beata [Maria de Araújo], obtive a seguinte resposta no dia quatro de Agosto do corrente ano, digo, deste ano: Ego sum Jesus, hóstia Sancta, hostia pura, hóstia immaculata: vivificavi sanguinem cordis ad peccatores; palavras estas que eu ouvi bem distintamente. [...] e instando eu para que Nosso Senhor se dignasse cumprir a promessa feita, isto é, de me revelar aquele mistério, começou ele a dizer [...]: Vide me feceris... Conservus tuus sum ET frutuum tuorum habentium testimonium Jesu. Deum adora testimonium sanguinis meiet spiritum prophetiae. Ego sum vitis vera, hóstia sancta, hostia pura, hóstia immaculata, jurando ele próprio e mandando-me que assim o jurasse por ele mesmo como Criador, como amigo, como esposo, como Redentor. ${ }^{22}$

Ora, Maria da Soledade afirmou que sua alma foi "testemunha de como a mesma revelação ao mesmo tempo era feita ao padre Cícero, o que se deu logo depois da Comunhão”. O que podemos depreender dessa relação? Primeiro, o fato do padre e da beata terem a revelação "ao mesmo tempo", mas em lugares distintos, indica a intimidade que eles tinham.

Em segundo lugar, o tom arrogante que "exige de Deus o cumprimento de uma promessa feita” permanece no relato do padre e é reproduzido nos relatos das mulheres. Terceiro, indicia que o relato do sacerdote foi usado para legitimar o depoimento da beata. Maria da Soledade era dirigida por este sacerdote desde 1889, pelo menos, e como as outras beatas, reforçou no seu depoimento a importância do seu confessor e é muito provável que ela tenha ouvido dele a citação em latim e a tenha memorizado.

Entretanto, não há dúvidas que o relato de Maria da Soledade é um dos mais eruditos, mas temos uma grande dificuldade no que diz respeito à sua formação. Não há documentação sobre essas mulheres e, ao que parece, não houve interesse

\footnotetext{
${ }^{21}$ Depoimento do Pe. Cícero em 17.07.1891 in "Cópia autêntica”, p. 18.

${ }^{22}$ Aditamento do padre Cícero em 14.09.1891 in "Cópia autêntica", p. 18.
} 
da Comissão em conhecê-las mais a fundo, assim, não é possível saber se elas estudaram em escolas ou tiveram educação doméstica, nem a que tipo de literatura religiosa elas tiveram acesso.

Outro exemplo que ilustra a riqueza do relato de Maria da Soledade é a alusão às várias passagens bíblicas, como no episódio em que lhe apareceram vários anjos em adoração ao Sacramento na Capela de N. S. das Dores:

Respondeu que no dia 25 de março, tendo-lhe ordenado o confessor, depois de uma benção a ela dada em honra da S. S. Virgem, que ela testemunha adorasse a Nosso Senhor ali presente no Sacramento da Eucaristia, especialmente manifestado naquelas hóstias transformadas em sangue, logo depois de sua comunhão, teve ela de ver na Capela do S. S. Sacramento diversos anjos e dentre eles três que se nomearam por seus próprios nomes, sendo um - Testes fidelis - outro - Reverentia - outro finalmente - Maravilha (SOLEDADE, 1891).

Dar nome aos anjos, ou melhor, obter deles uma identificação, aparece aqui como outro recurso para dar credibilidade a narrativa, pois denota um conhecimento das leituras sagradas. Um dos anjos citados, Testes fidelis, que significa Testemunha Fiel, é citado nos versículos 37 do Salmo 89 na Bíblia: “Para sempre será sua linhagem, seu trono como um sol à minha frente; como a lua que dura sem cessar, testemunha fiel no firmamento”.

Conjeturamos que a menção de Testes fidelis adquire um sentido profético ao proclamar a presença constante dos anjos em adoração ao "Sangue Precioso" de Cristo. Reverentia, do latim, Reverência, aparece na Bíblia não como um anjo, mas como uma qualidade a ser exigida do fiel: "de atitude de reverência, fluem com naturalidade os atos de obediência” (Bíblia de Jerusalém, 2 Co 7.1). E Maravilha deve se referir possivelmente aos diversos fatos extraordinários realizados por intervenção divina (Bíblia de Jerusalém, Mt 21.15).

O relato mais ousado de Maria da Soledade a transformou em uma espécie de guia de almas. Em missão recebida de Jesus Cristo como penitência sacramental, ela teria que acompanhar o sufrágio de três eclesiásticos: dois bispos e 
um cardeal que iriam encontrá-la na Capela de Nossa Senhora das Dores para adorar ao Sangue Precioso e assim conseguirem sair do Purgatório:

No dia 23 de dezembro de 1890, por ocasião de confessar-me, foi-me imposta como penitência sacramental dar-me toda a Deus para em honra do preciosíssimo sangue de Jesus, das dores de sua Mãe S. S. e maior gloria da Trindade S. S., tomar sobre mim as penas de três almas que fossem de papas e assim libertá-las do Purgatório. Sucedeu, porém, que Nosso Senhor não aceitou essa oblação em relação aos papas e substituiu aplicando-a as almas de um Cardeal e dois bispos. [...] - Episcopus Joachinus et Episcopus Petrus - o primeiro que foi antecessor do Arcebispo da Bahia D. Luiz, o segundo, que foi bispo do Rio de Janeiro. Desde esse dia até o dia seis de janeiro do ano seguinte, estas três almas vinham todos os dias a assistir a missa, colocando-se os dois bispos de um e outro lado e o Cardeal no meio; todos possuídos do maior acatamento [...]. (SOLEDADE, 1891).

Identificamos os bispos como Dom Joaquim Gonçalves de Azevedo (18141879), que era maranhense e foi o sétimo bispo de Goiás (1866), sendo assistido na época pelo então bispo do Ceará, D. Luís Antônio dos Santos. Em 1876 foi nomeado Arcebispo de São Salvador da Bahia e Primaz do Brasil e faleceu em seis de novembro de 1879.

O segundo bispo seria, claramente, o ex-bispo do Rio de Janeiro, Pedro Maria de Lacerda. Nascido em 31 de outubro de 1830, sagrado bispo em Mariana por Dom Antônio Ferreira Viçoso, famoso pela disseminação do ultramontanismo no Brasil e conhecido pela chamada "Questão religiosa" que envolveu a prisão de dois bispos D. Antônio de Macedo Costa e D. Vital Maria de Oliveira por ordem do imperador D. Pedro II. Ele faleceu em 12 de novembro de 1890 e sua morte foi muito divulgada nos jornais da época, tendo sido provavelmente comentada pelos sacerdotes no povoado de Juazeiro, embora não encontremos nos documentos analisados nenhuma outra referência aos bispos e ao cardeal.

As almas iam todos os dias assistirem a missa, "colocando-se os dois bispos de um e outro lado e o Cardeal no meio; todos possuídos do maior acatamento", até que no dia 26 de dezembro sucedeu que ao tocar o Sanctus, o Cardeal: 
[...] inflamado com as chamas de amor que, saindo do Sacrário envolviam o Sacerdote oficiante e se transmitiam ao mesmo Cardeal, sentiu-se incitado a subir ao altar, onde prostrado com a face em terra, em adoração ao sangue de Jesus que então caía sobre ele, como chuva, exclamou: '- oh, amor!' conservando-se nessa posição até o fim da missa. (SOLEDADE, 1891).

Continuaram o processo de sufrágio pelos dias que se seguiram e no dia 28, no momento de consagração da hóstia, o rosto do Cardeal desfez-se em chamas e ele exclamou:

Oh! levita do Santuário, tenro arbusto sacerdotal, vaso de eleição, chamado a serdes sentinela em Israel, vós doce esperança de nossos gozos e resplendores eternos, chegai-vos a este vulcão de amor, (e isto dizendo, apontava para um retábulo do Sagrado Coração de Jesus e o tabernáculo e a caixa de vidro contendo as partículas transformadas em sangue;) atiraivos às ardentes chamas, acendei-vos em seu abrasado ardor para serdes luz e calor no meio das nossas trevas; terminando com dizer duas vezes 'lucemea, ardens, ardens'. (SOLEDADE, 1891).

A presença do fogo na narrativa de Maria da Soledade está diretamente relacionada ao ato de purgar: "desfazendo-se em chamas", "vulcão de amor", "ardentes chamas”, "abrasado ardor”; justamente porque não existe purgação sem o fogo purgatório, pois, “o fogo porá à prova a obra de cada um” (Bíblia de Jerusalém, 1 Co 3.13).

Jean-Claude Schmitt - em sua pesquisa sobre as aparições de fantasmas no medievo - aprofunda tal discussão sobre o imaginário do morrer, ao afirmar que a existência dos mortos está diretamente ligada ao que os vivos imaginam para si: "Diferentemente segundo sua cultura, suas crenças, sua época, os homens atribuem aos mortos uma vida no além, descrevem os lugares de sua morada e assim representam o que esperam para si próprios” (SCHMITT, 1999, p. 15).

Mapeando a crença no espaço intermediário do Purgatório, Jacques Le Goff também apontou para esta ligação entre o imaginário dos vivos e a morte, ao afirmar que os "mortos não existem senão pelos e para os vivos" (LE GOFF, 1993, p. 251). Em outras palavras: as práticas e crenças ligadas à morte e aos 
mortos são produtos socioculturais dos vivos e refletem as expectativas destes em relação a uma nova vida, tida como imortal, tendo início após o término da vida presente ou vida terrena.

Michel Vovelle assinala que o termo purgatorium, recebeu caução do papa Inocêncio III, entre 1170 e 1200, "no momento em que uma nova necessidade de justiça na sociedade laica favorece a eclosão do conceito de julgamento individual" (VOVELLE, 2010, p. 27). Não por acaso, esse século marcou a institucionalização do Purgatório, um espaço intermediário entre o Céu (para onde vão as almas inteiramente boas) e o Inferno (lócus das almas inteiramente más). O Purgatório surgiu enquanto um terceiro espaço da geografia do além, em que as pessoas situadas no limite entre as inteiramente boas e as inteiramente más podiam remir seus pecados veniais, para assim atingir o ingresso no Paraíso Celeste.

A duração das penas no Purgatório, segundo Jacques Le Goff, está "submetida a um procedimento judicial complexo". O período de purgação de uma alma depende da misericórdia de Deus, "simbolizado pelo zelo dos anjos ao arrancar as almas aos demônios", dos méritos pessoais exibidos em vida pelo falecido, e dos "sufrágios da Igreja suscitados pelos parentes e amigos do defunto" (LE GOFF, 1995, p. 253). A crença nesse espaço intermédio acabou por instituir novos laços de solidariedade entre os vivos e seus mortos, na medida em que os primeiros podiam contribuir com sufrágios para mitigar as penas dos últimos.

O fogo purgatório ganhou, então, um sentido de purificação, ele rejuvenesce e imortaliza e como informa Le Goff: "o Purgatório antes de ser considerado um lugar foi primeiro concebido como um fogo" e, completa: “A teologia católica moderna distingue um fogo do Inferno, primitivo, um fogo do Purgatório, expiatório e purificador e um fogo de julgamento, probatório" (LE GOFF, 1993, p. $22 ; 62)$.

O fogo também pode ser associado, como explica Redondi, à própria hóstia consagrada: "como para significar que a luz tinha uma função simbólica essencial 
numa teologia centrada verticalmente sobre seu núcleo eucarístico. A disposição axial da Trindade, em relação à hóstia culmina assim na luz do fogo" (REDONDI, 1991, p. 229). Assim, o fogo que emana do corpo do Cardeal e que abraça a hóstia no Sacrário tem essa dupla função de purificação e purgação, simbolizando ainda o poder maior da hóstia consagrada como centro de toda a cosmologia cristã.

As almas continuaram a aparecer continuamente, até que no dia 5 de janeiro o cardeal revelou sua identidade, dizendo três vezes: "Ego sum Cardinalis Pecci"23. O cardeal a que se referia Maria da Soledade é provavelmente o Cardeal Giuseppe Pecci (1807-1890), ex-prefeito da Congregação para Estudos do Vaticano, que havia falecido em oito de fevereiro de 1890. Este cardeal era também irmão do papa da época, Gioacchino Pecci, conhecido como Leão XIII²4.

Mais tarde, em junho de 1892, o padre Alexandrino afirmaria que a visão fora "fabricada" no intuito de "dispor bem o Santo Padre em favor de Juazeiro", pois corria na região a notícia de que "Leão XIII teve notícia disto, chorou e ficou bem disposto em favor da causa" 25 . O que ratifica que o caráter de sigilo dos depoimentos não foi respeitado nem pelas testemunhas, nem pelos membros da Comissão. Finalmente, no dia 6 de janeiro, também durante a missa e depois da benção do S.S. Sacramento:

[...] o Cardeal, como que fora de si, somente possuído de Deus, erguendo as mãos exclamou: Oh! Caríssimo e dedicado irmão, que amor, que ternura e que reconhecimento não devo eu ter para convosco, quando considero que fostes o instrumento pelo qual quebraram-se cadeias que me detinham nesse cárcere, depois de minha morte; por meio e intermédio de vós é tempo hoje de eu consumar todos os meus trabalhos, subindo da terra ao Céu para habitar, reinar e glorificar aquele que é o princípio e o fim de todas as cousas; vou por tanto entrar no gozo do meu Senhor; e assim, como tomastes parte no meu doloroso e delatado exílio, tomai hoje parte nesta enchente de alegria de que a minha alma está penetrada, e que é o fim de tantas dores, lágrimas e gemidos. Eu me vou para o seio de Deus... para acabar de consumar as minhas vitórias sobre o mundo, o inferno e o pecado, pela minha entrada gloriosa e triunfante em

\footnotetext{
${ }^{23}$ Tradução minha: “Eu sou o Cardeal Pecci”.

${ }^{24}$ Consultamos o site do Vaticano que contém a lista dos papas e cardeais da Igreja Católica, ordenada por século. Disponível em http://www.vatican.va, além da Biblioteca Electrónica Cristiana, BEC.

${ }^{25}$ DHDPG/ CRA 04,07: Carta do Pe. Alexandrino a D. Joaquim de 28.06.1892.
} 
seu reino; [...] - e isto dizendo, voou para o céu, acompanhado de seu Anjo Custódio e de todos os santos que foram seus protetores e advogados neste mundo.

As almas dos bispos continuaram a ser sufragadas por mais alguns dias, até que, no dia 18 de janeiro, foi a vez de Dom Joaquim Gonçalves "subir triunfante aos céus", seguido por Dom Pedro de Lacerda, no dia 2 de fevereiro seguinte. A mensagem implícita no relato de Maria da Soledade manifestava assim uma inquietação comum a todos os crentes do "Sangue Precioso": Ora, se a Capela de Juazeiro serviu de purgatório às almas que em vida pertenceram a mais alta hierarquia da Igreja, porque o bispo continuava negando a sacralidade dos fenômenos que ali se manifestavam?

Provavelmente, a narrativa foi construída a partir de informações fornecidas pelos próprios sacerdotes, incluindo aí o padre Cícero que tinha acesso aos jornais da Capital que circulavam na época. E, paradoxalmente, o respeito à hierarquia presente na narrativa não existia com relação à própria Diocese!

Tudo nesses inquéritos transgride as premissas de um Processo eclesiástico convencional. Inferimos que a extrema condescendência do bispo ajudou a propagar, dar visibilidade e estimular a credibilidade do caso. Tudo que a Igreja não queria nem precisava. Para isso, certamente, contou a tibieza e insegurança do bispo. Segundo ela, depois disso, o próprio Cristo dava instruções de como deveria ser organizado o culto ao "Sangue Precioso":

Nosso Senhor fez-me ver que assim como os Padres Franciscanos eram os guardas do Santo Sepulcro assim também haviam eles de ser os guardas do sangue derramado das hóstias consagradas aqui nesta Povoação do Juazeiro $^{26}$.

Jahel Wanderley também havia sugerido em seus depoimentos a fundação de uma ordem "que se encarregasse do culto perpétuo da S. S. Trindade, bem como

${ }^{26}$ Relatório final do Pe. Clicério Lobo de 22.12.1891 in “Cópia autêntica...", p. 62. 
que fosse sempre aqui bendito e louvado seu precioso sangue" (ARAÚJO, 1891)27; com um núcleo masculino formado pelos franciscanos e outro núcleo feminina segundo a regra de Santa Teresa (CABRAL, 1891). ${ }^{28}$ A escolha de padres Franciscanos não surpreende, pois essa ordem medicante é colocada em oposição à ordem dos padres lazaristas franceses que naquele momento dirigia a Diocese cearense.

É importante lembrar que a própria evangelização da região foi feita pelos padres Capuchinhos italianos, ordem que surgiu na Itália em 1525, como um terceiro ramo da Ordem dos Franciscanos, cuja prédica era fortemente marcada por elementos da Paixão de Cristo, na qual a memória dos pecados e da condenação eterna é enfatizada continuamente através de práticas que estimulam as penitências, a flagelação e o padecimento do corpo em uma contínua imitatio Christi. A predileção por Santa Teresa também não é de admirar, uma vez que esta santa é uma das representantes mais conhecidas de um ideal contemplativo que mesclava a austeridade conventual à experiência mística e o íntimo contato com Deus ${ }^{29}$.

\section{Embusteiras e falsas: o veredito da Santa Sé}

Alegando que os padres foram desobedientes às recomendações de como proceder aos exames, Dom Joaquim recusou o primeiro inquérito e afirmou que não só eles, mas também o padre Cícero e os outros sacerdotes foram enganados pelos artifícios de Maria de Araújo e das outras beatas, imitadoras da primeira.

Como dissemos, o bispo deveria apresentar relatórios periódicos ao Internúncio sobre o avanço das retratações. Apesar da obstinação que algumas mulheres demonstravam, em janeiro de 1895, quase um ano após a publicação dos

\footnotetext{
${ }^{27}$ Aditamento de Maria de Araújo de 11.09.1891 in "Cópia autêntica", p. 16.

${ }^{28}$ Aditamento de Jahel Cabral de 05.10.1891 in "Cópia autêntica", p. 54.

${ }^{29}$ Entretanto, esta é apenas uma hipótese, pois não há documentação suficiente que comprove que elas liam esses textos.
} 
Decretos da Santa Sé, cinco beatas, entre elas, as beatas Jahel Cabral e Maria da Soledade haviam confessado sua culpa, "seus erros e desvios"3o, e a partir daí os sacerdotes mais resistentes também começaram a ceder.

Pressionado pelos “crentes" do Sangue Precioso e por parte do clero, em maio de 1893, Dom Joaquim decidiu enviar o Processo para Roma e deixar à Santa Sé, a responsabilidade pela condenação definitiva dos “pretensos milagres”. Em maio de 1893 a documentação foi enviada para a Santa Sé, mais especificamente para o Cardeal Rafaelle Monaco la Valleta (1827-1896) do Supremo Tribunal da Penitenciária Apostólica,que naquele momento era o órgão responsável por examinar tudo o que se referia às doutrinas da Igreja Católica em conjunto com a Congregação para a Doutrina da Fé.

A documentação compreendia o primeiro inquérito conduzido pelos padres Clicério da Costa Lobo e Francisco Ferreira Antero em 1891, mais os documentos enviados pelo padre Alexandrino e a Carta Pastoral de 1893. Um ano depois do envio do Processo, foi exarado um parecer assinado pela mesa de cardeais da Congregação:

Que os pretensos milagres e outras coisas sobrenaturais que se predicam de Maria de Araújo são prodígios vãos e supersticiosos, e implicam gravíssima e detestável irreverência e ímpio abuso à Santíssima Eucaristia, por isso o juízo apostólico os reprova e todos devem reproválos, e como reprovados e condenados devem ser tidos ${ }^{31}$.

Em 1894, a Congregação para a Doutrina da fé, exarou sua decisão incontestável e o bispo Dom Joaquim anunciou sua vitória em uma Carta Pastoral. Já em 1898 foi publicado um Relatório que ratificava as decisões de 1894. Neste, são citadas algumas mulheres, como a beata Antônia Maria da Conceição, acusada

\footnotetext{
${ }^{30}$ CPR/CRA: 07,01. Carta de D. Joaquim ao Internúncio Apostólico, Frei Jerônimo em 04.02.1895.

31 Tradução minha: "Minuta di lettera approvata dagli Emi. in feria IV de Aprile 1894. [...] Praetensa miracula alia que supernaturalia quae de Maria de Araújo praedicatur vana esse et superstitiosa ostenta, ac gravissimam detestabilen que irreverentiam et impiumabusum SSmãe. Eucharistia e continerei deo que indicio apostólico reprobari, et abomnibus reprobandu esse et pro reprobatis et condemnatis habenda." Feria IV, Die 4 Aprilis 1894, Decreta Universa, ACDF.
} 
de "confirmação de falso milagre" e de "juramento em falso", o texto do Relatório recorda:

[...] ela declara abertamente que não teve nenhuma revelação, de qualquer tipo que seja; que ela jamais foi honrada com aparições divinas, nem daquelas com a Santíssima Virgem; que ela jamais foi a Roma em espírito, nem ao céu, nem ao Inferno, nem ao Purgatório. [...] Ela disse que os eventos em Maria de Araújo, não lhe tinham causado nenhuma surpresa, porque era sua convicção de que este devota tinha forjado esta história dos supostos milagres com habilidade e malícia, desde o início. E, finalmente, que todo o seu depoimento no processo sobre os fatos de Juazeiro era um tecido de mentiras32.

Outras mulheres são citadas en passant: Maria da Soledade, condenada como embusteira por dentre outros abusos, dar uma medalha de São José ensanguentada e dá-la a beijar pelo povo; Anna Leopoldina de Aguiar e Mello, embusteira por alegar que uma hóstia ensanguentada lhe foi dada por Cristo em uma de suas viagens ao Purgatório; Jahel Wanderley Cabral, embusteira, por aparecer com um coração feito de hóstias e dizer que este lhe havia sido dado por Deus, quando estava no Purgatório. Joana Tertulina de Jesus e Maria das Dores do Coração de Jesus, condenadas por extrema pertinácia e por interporem recurso falso ao Sumo Pontífice.

Foram proibidas visitas a Maria de Araújo ou às mulheres "como ela culpáveis nos embuste de Juazeiro; era urgente que todos os escritos e medalhas fossem recolhidos e queimados; os panos ensanguentados (que tinham sido roubados da Matriz do Crato) deveriam ser devolvidos sob pena de excomunhão para aqueles que os mantivessem, e com isso, o bispo acreditava no fim das romarias e que os sacerdotes “desviados” voltariam “à bons caminhos” 33 .

\footnotetext{
${ }^{32}$ Tradução minha: “Elle déclara ouvertement que jamais elle n'avait eu aucune révélation, de quelquer sorte que ce soit; que jamais elle n'a été honorée d'apparitions divines, ni de celles de la T.S.. Vierge ; que jamais elle n'est allée à Rome en esprit, ni au Ciel, ni aux Enfers, ni au Purgatoire. [...] Elle dit que les faits survenus à Marie de Araújo, ne lui avaient causé aucune surprise, parceque c'était sa persuasion que cette dévote avait echaffaudè cette histoire des miracles supposés avec habiletè et malice, à son but. Et finalement, que toute sa déposition dans le procès sur les faits de Joaseiro, était un tissu de mensonges". Rerum Variarum 1898/128. Vol. II, Doc. 16. ACDF.

${ }^{33}$ Carta de D. Joaquim Vieira ao D. Girolamo Maria Gotti em 03.08.1894. B. 76, Fasc. 369, Doc. s/n. ASV.
} 


\section{Considerações finais}

Segundo Certeau, a escrita do outro é sempre uma escrita conquistadora. Do mesmo modo, a relação do historiador com sua fonte é também uma relação de poder instaurada nos jogos de sedução que se estabeleceram entre um e outro. Parti do pressuposto de que os fenômenos narrados no processo eclesiástico, a partir de 1891, pelas beatas do Cariri cearense são os eventos fundadores de um dos maiores espaços devocionais do Brasil.

O véu do esquecimento, social e historiográfico, foi jogado sobre essas mulheres, após a Santa Sé declarar a sua culpa. Aqui a ideia de esquecimento está ligada a noção de desmascaramento. Uma vez tidas como atrizes de uma farsa, as beatas deveriam sair de cena. Assim, o esquecimento historiográfico dessas mulheres foi acima de tudo, um esquecimento social que buscou e conseguiu através das inúmeras técnicas do 'fazer falar uma verdade', que elas não só negassem suas narrativas "maravilhosas", mas também, que desaparecessem do cenário.

Quando essas mulheres começaram a contar como a Paixão de Cristo se repetia no povoado de Juazeiro desde 1889, aquele lugar se tornou um espaço sagrado. Para a Diocese o espaço dito 'sagrado' se configurou como "uma farsa imoralmente urdida e pessimamente executada" 34 , é o espaço do dantesco, do fanatismo. Para os crentes no Sangue Precioso, o espaço sagrado é o "teatro dos acontecimentos (MARROCOS, 1891)"35, um espaço de milagres, de devoção e salvação.

É importante enfatizar que, em seus relatos, elas pouco falam sobre a vida de Maria de Araújo. Ao contrário, exaltam suas próprias experiências e incluem em suas narrativas elementos por vezes, até mais elaborados do que aqueles presentes

\footnotetext{
${ }^{34}$ CPR/CRA: 04,09. Carta do Pe. Alexandrino a D. Joaquim de 09.08.1892.

${ }^{35}$ Depoimento de José Marrocos de 12.10.1891, In “Cópia autêntica...", p. 68.
} 
no relato de Maria. Essas mulheres, no entanto, desaparecem imediatamente após suas retratações. Ficamos sabendo através do padre Alexandrino sobre o destino de uma ou outra, mas é como se suas vidas fossem apenas rabiscos na areia da praia cujo mar, com sua violência, apagou sem hesitar.

A especificidade aqui é dada pelo contexto, pelo momento político da Igreja que não acolhia mais aquele tipo de experiência e, claro, pela ação de Cícero, que ganhou muito destaque e poder na região. Para a Diocese cearense isso representou uma vitória: se não foi possível acabar com as romarias a Juazeiro, ao menos, as mulheres saíram de cena.

\section{REFERÊNCIAS}

ALGRANTI, Leila Mezan. Honradas e devotas: mulheres da colônia. Rio de Janeiro: José Olympio; Brasília: EdUnb, 1993.

Bíblia de Jerusalém. São Paulo: Paulus, 2002.

BORRIELO, L. Dicionário de Mística. São Paulos: Paulus, 2003.

CERTEAU, Michel de. La fable mystique. Paris: Gallimard, 1982.

DELUMEAU, Jean. Mil anos de felicidade. Uma história do paraíso. São Paulo:

Companhia das Letras, 1997.

DElumeAu. Jean. O que sobrou do Paraíso? São Paulo: Companhia das Letras, 2003.

FRANCO, Jean. Las Conspiradoras: La Representación de la mujer en México. México: Terra Firme/Fondo de Cultura Econômica, 1993.

GÉLIS, Jacques. O Corpo, a Igreja e o Sagrado”. In: CORBIN, A.;COURTINE, JJ.;

VIGARELlO, G. História do Corpo. Petropólis, RJ: Vozes, 2008. p. 19-130.

GONÇALVES, Margareth de Almeida. Império da Fé: andarilhas da alma na era barroca. Rio de Janeiro: Rocco, 2005.

LE GOFF, Jacques. La naissaince du Purgatoire. Paris: Gallimard, 1981. 
LIMA, Luís Filipe Silvério. O império dos sonhos. São Paulo: Alameda, 2010.

NOBRE, Edianne. O Teatro de Deus: as beatas do Padre Cícero e o espaço sagrado de Juazeiro. Fortaleza: Editora IMEPH, 2011.

SCHMITT, Jean-Claude. Os vivos e os mortos na sociedade medieval. São Paulo: Companhia das Letras, 1999.

VALENTE, José Angel. Variaciones sobre el pájaro y la red. Barcelona: Tusquets, 1991.

VOVELLE, Michel. As almas do purgatório. São Paulo: UNESP, 2010. 